tor or the consultant they know and trust to organize their care at the last. At the same time, of course, we feel that the special units, with their expertise and their teach ing, will help to set-have already set-new standards in this field.-I am, etc.,

ERIC WILKES

Department of Community Medicine University of Sheffield

\section{Effect of Oxprenolol on Heart Rate}

SIR,-Dr. U. Thadani and others (20 January, p. 138) found that the resting heart rate was higher after intravenous than after oral administration of oxprenolol.

We recently gave oxprenolol intravenously $(0.1$ and $0.2 \mathrm{mg} / \mathrm{kg}$ body weight) and orally (40 and $80 \mathrm{mg}$ ) to six normal volunteers under double-blind conditions in an investigation to determine whether it influenced central nervous activity at these doses. No significant changes were found in critical flicker frequency, hand-eye co-ordination, or serial subtraction, nor did the resting heart rate after intravenous oxprenolol differ from that after a placebo. After oral oxprenolol however, there was a significant, doserelated reduction in resting heart rate $(\mathrm{P}<0.05)$, most marked at four hours. A possible explanation of these observation could be the formation of a metabolite after oral administration which has a poten $\beta$-receptor blocking action without the intrinsic activity possessed by the paren compound.-We are, etc.

ANNMARIE HEDGES Paul TURNe

Department of Clinical Pharmacology,

St. Bartholomew's Hospital,
London E.C.1

\section{Immunosuppression and Malignancy}

SIR,-I wonder whether the statement in the opening paragraph of your leading article (23 September, p. 713) to the effect that the concept of the existence of such a state as "immunosuppression" was first put forward in 1959 is wholly correct.

In $1924^{1}$ you published an article by me entitled "Early Pregnancy and Epitheliomata" which I feel put forward just this theory. In those days the "epitheliomata" under study were chorionic epitheliomata. An extract reads as follows:

"The fundamental point to be kept in view in a study of any disease is that the norma human body is fully equipped to withstand disease, and it should be our duty to find out in the first instance, why its resistance failsnot the nature of the attacking force. Remember that the tissues are fully equipped at the start therefore the weakness is on their side. Working from this standpoint, we would have to allow that the body tissues are prepared to, and normally can, resist the growth of an epithelioma, and that if the tissues are prepared against this particular growth they will resist any invading growth, whether malignant or not. This leads me to suggest that, as result of this preparedness, the body will resis the normal invasion of the chorionic epithelium. The chorionic villi are able to in vade the uterine wall, and so in some way this resistance has been overcome-but how? That the body shows signs of a reaction taking place is evidenced by the general malaise, nutriticna disturbances, and sickness of pregnancy. We also know that lutein cells have appeared in the ovary after the ovum left it and these cells seem to grow in proportion to the rate of growth of the placenta, and that when the placenta ceases to grow, at the third month, these lutein cells also cease to grow. That there is some connexion between these two points is admitted. It is also generally admitted today that the function of the corpus luteum is that of an internal secreting gland. When Fränkel found that destruction of the corpus luteum in pregnant rabbits resulted in abortion, he concluded that it produced a secretion which maintained the implantation and growth of the ovum in utero. I suggest that this might be modified by saying that the secretion produces a body reaction, the result of which is to provide an antibody to the normal 'body resistance to any invasion,' and so the chorionic epithelium is able to maintain its hold, and that Fränkel's experiment allowed the normal body resistance full play so that the chorionic epithelium was repelled. Pregnancy sickness is evidence of this auto-inoculation. This also explains the abnormal lutein activity found in chorionic epithelioma. Overproduction of secretion results in completely antidoting resistance, and so invasion continues wildly."

Is not all this the theory of "immunosuppression" or, as I would call it more simply, "defensive or physiological suppression"? Are not the warnings issued recently pointing to the possible carcinogenic nature of certain oestrogen-containing antiovulation pills when given to normal women, up-to-date practical evidence in support of the "antidoting resistance" concept of both pregnancy and malignancy? Does not the rejection by the tissues of tissue transplants point also to the existence of "a resistance of the body to any invasion" as I have indicated earlier?

All oestrogens appear to be concerned with reparative cell proliferative processes. Some, such as luteal oestrogen, normally act specifically on endometrial cells, while adrenal oestrogens have a predilection for mammary and prostatic tissues. Others are responsible for the physiological proliferation of those body cells normally capable of multiplying in the replacement of cells lost in the course of ordinary "wear and tear." It is conceivable that overactivity of any of the various oestrogens may result in a lowering of the body resistance so that even norinally multiplying cells, or cells multiplying in response to any local stimulus, may invade surrounding tissue and so bring about a state of malignancy, since as the cells multiply they would call up more and more of their particular oestrogen.

Malignancy could be regarded as a pseudopregnancy.-I am, etc.

Charles W. A. EMERY

St. An
Lancs

1 Emery, C. W. A., British Medical fournal, 1924,

Toxocara Larval Papillitis

SIR,-I have read with interest the paper by Professor C. I. Phillips and Mr. A. D. MacKenzie (20 January, p. 154) reporting a case of toxocara larval papillitis.

Although there was no eosinophilia in this case there is no reason to doubt the correctness of the diagnosis on this score; many cases of toxocariasis present with a normal white blood count. ${ }^{1}$ The negative skin test and negative fluorescent antibody test found initially must, however, cast doubt on the diagnosis. The subsequent positive fluorescent antibody test may indicate not a natural infection but a rise of antibody in response to the intradermal injection of toxocara antigen.-I am, etc.

Amersham General Hospital,

D. H. GARROW Bucks

1 Garrow, D. H., and Kane, G. J., Archives of Garrow, D. H., and Kane, G. J., Are
Disease Childhood, 1973, 48, 81 .

\section{Grants for Postgraduate Study}

SIR,-I read your leading article "Food for Thinking" (20 January, p. 126) with interest. Moreover, I agree wholeheartedly with the sentiments and motivations expressed, culminating in "this is probably one research area in which the factors limiting progress are money and men rather than shortage in ideas."

As it happens, I am at present trying to fulfil the need for "men"; having qualified in medicine in London two years ago I am now extending my knowledge through a postgraduate (M.Sc) course in human nutrition lasting one academic year. However, I am now running into severe financial difficulties and consequently my completion of the course is placed in jeopardy, I have found it virtually impossible to obtain a grant or any other form of assistance. The Medical Research Council offers only two grants each year for our class of 20 students, for which one has to apply nine months before commencement of the course. As you will realize, this may prove very awkward to a junior hospital doctor whose appointments last from six months to a year. Overseas students are practically all assisted by World Health Organization and British Council grants. There is a body called the Educational Grants Advisory Service run by the National Council for Social Services. Their reply to my inquiries was frankly pessimistic-“financial help for postgraduate students seems at present time very remote indeed"-and offered no further suggestions.

At present I am doing part-time G.P. relief work at night, which is very interesting but can only distract me from the subject I should be putting all my efforts into.

If young doctors are to be encouraged to go into specialized fields, then clearly more will have to be done to enable them to do so.-I am, etc.

London W.4

STEPHEN J. O'KeEFE

\section{Suicide Rate}

Sir,-Dr. B. M. Barraclough (3 February, p. 293) claims to document the decline in the suicide rate among young persons in England and Wales by noting a decline from 1963 to 1970 . This does not refute the increase I noted (9 December, p. 612) from 1957 to 1967. The suicide rate fluctuates from year to year and trends can be identified only by data from several successive years, so that the reliability of changes can be ascertained.

Dr. Barraclough noted that first admissions for psychiatric disorders among persons aged 15-19 rose from 1964 to 1970. This may reflect increasing psychiatric facilities for the young, more favourable attitudes toward psychiatric help in the young (and their parents), or an increase in psychiatric disorders among the young. This last explanation, if correct, constitutes a serious challenge for psychiatry. Dr. Barraclough 